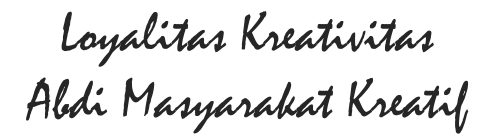

Loyalitas Kreativitas

Aldi Masyarakat Kreatif

P-ISSN 2722-2101, E-ISSN 2722-4201

Program Studi Ekonomi Manajemen Universitas Pamulang

Jurnal LOKABMAS Kreatif Vol. 01, No. 03, Hal. 1-6

Email:jurnalkreatif.manajemen@gmail.com

\title{
BERBAGI BERSAMA KAUM DHUAFA BINAAN LAZ NAHWA NUR YANG TERDAMPAK COVID-19
}

\author{
Ahmad Maulana Irfanudin, Ismail Jamil, \\ Muhamad Faozan Afandi \\ Dosen Ekonomi Fakultas Ekonomi Universitas Pamulang \\ Email dosen01868@unpam.ac.id,
}

\begin{abstract}
ABSTRAK
Tujuan dari Kegiatan Pengabdian Kepada Masyarakat adalah untuk melaksanakan salah satu Tri Dharma Perguruan Tinggi. Selain itu diharapkan dapat memberikan bantuan sosial kepada para kaum dhuafa terdampak pandemi corona virus desease 2019 (Covid-19) di wilayah kabupaten Bogor yang tersebar kurang lebih di 40 kecamatan yang belum terjangkau dan mendapat bantuan kebutuhan pokok.

Metode pelaksanaan pengabdian ini dilakukan secara sistematis dan terbagi dalam beberapa kegiatan mulai dari tahap survei berupa sosialisasi yang dilakukan dengan menyusun program-program yang akan disampaikan saat kegiatan pengabdian masyarakat dilangsungkan, meliputi: penyusunan materi dan jadwal serta pembagian tugas tim pengabdian serta survei lokasi pengabdian. Tahap sosialisasi yaitu berupa silaturahmi dengan Ketua dan pengurus Yayasan LAZ Nahwa Nur, menyampaikan maksud dan tujuan pengabdian serta hasil yang diharapkan. Pada tahap ini juga dilakukan perjanjian kerjasama pengabdian serta menentukan jadwal acara berlangsung. Tim pelaksana kegiatan pengabdian pada masyarakat adalah dosen Fakultas Ekonomi program studi Manajemen S1 dan Akuntansi S1 beranggotakan 5 orang. Tim pengabdian akan memberikan materi tentang Strategi Melakukan Bisnis melalui Media Daring dalam Rangka Penanggulangan Dampak Covid-19 pada sektor ekonomi, dialnjutkan dengan pemberian pelatihan melalui media video konferensi oleh dosen UNPAM.

Hasil pengabdian masyarakat yang diperoleh adalah bertambahnya keilmuan bagi Para Peserta mengenai bagaimana cara mengoptimalkan sumber daya yang dimiliki dengan pemanfaatan media daring yang mulai berkembang sehingga mereka memiliki bekal tambahan untuk mendapatkan penghasilan tambahan. Harapan kami dengan pengabdian ini dapat memberikan bantuan sosial secara langsung dan tepat sasaran, serta membuka wawasan masyarakat khususnya terdampak pandemi Covid-19 tentang strategi pengembangan bisnis melalui media daring dan dengan ilmu yang diperoleh pada kegiatan ini diharapkan mampu memberikan semangat baru bagi para dosen dan tenaga pengajar sebagai contributor yang memotivasi khususnya bagi masyarakat sekitar yang membutuhkan, terlebih disaat pandemi masih berlangsung.
\end{abstract}

\section{Kata Kunci: Bantuan Sosial, Strategi Bisnis, Daring}

\section{ABSTRAC}

The purpose of community service is to implement one of Tri Dharma colleges. Other than that, is to provide social assistance to the poor affected by the 2019 corona virus disease (Covid-19) in the Bogor regency area which is spread over approximately 40 sub-districts that have not been reached and receive basic needs assistance.

This method of implementing community service is carried out systematically and is divided into several activities starting from the survey stage in the form of socialization which is carried out by 


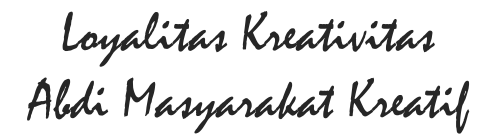

Loyalitas Kreativitas

Aledi Masyarakat Kreatif
P-ISSN 2722-2101, E-ISSN 2722-4201

Program Studi Ekonomi Manajemen Universitas Pamulang

Jurnal LOKABMAS Kreatif Vol. 01, No. 03, Hal. 1-6

Email:jurnalkreatif.manajemen@gmail.com

compiling programs that will be delivered when the community service activities take place, including: the preparation of materials and schedules as well as the division of tasks of the service team and survey of service locations. The socialization stage is in the form of a friendly meeting with the Chair and management of the LAZ Nahwa Nur Foundation, conveying the aims and objectives of the service as well as the expected results. At this stage a cooperation agreement is also carried out and determine the schedule for the event to take place. The implementing team of community service activities is a lecturer in the Faculty of Economics, a study program of Management S1 and S1 Accounting consisting of 5 people. The dedication team will provide material on the Strategy for Doing Business through Online Media in the Context of Overcoming Covid-19 Impacts on the economic sector, followed by providing training through video conferencing media by UNPAM lecturers.

The result of community service obtained is increasing knowledge for Participants on how to optimize their resources by utilizing online media that are starting to develop so that they have additional provisions to earn additional income. It is our hope that this dedication can provide direct and targeted social assistance, as well as open community insights, especially those affected by the Covid-19 pandemic about business development strategies through online media and with the knowledge gained from these activities, which are expected to provide new enthusiasm for lecturers and staff teachers as contributors who motivate, especially for surrounding communities who need it, especially when the pandemic is still ongoing..

\section{Keywords: Social Assistance, Business Strategy, Online}

\section{PENDAHULUAN}

Corona virus desease (Covid-19) yang adalah penyakit menular yang disebabkan oleh virus SARS-COV-2, yang sering juga disebut Virus Corona. Virus Corona sendiri masih merupakan keluarga yang sama dari virus yang telah ada sebelumnya, SARS dan MERS. Virus Corona kini diindikasi menyebar lewat penularan langsung manusia ke manusia. Dikarenakan jenis virus yang baru seperti Covid-19, tingkat penularan menjadi sangat tinggi, ditambah sistem kekebalan tubuh manusia yang belum mengenal virus seperti sebelumnya. Saat ini, peneliti di penjuru dunia termasuk Indonesia melakukan Research and Development untuk mencari jalan keluar untuk menyembuhkan efek dari virus covid-19.

Hal ini menyebabkan sebagian besar Pemda (Pemerintah Daerah) khususnya di dareah padat penduduk memberlakukan Lockdown di area wilayah setempat untuk membantu meminimalisir penularan virus tersebut. Karenanya, Pemerintah Daerah mengajukan Pembatasan Sosial Berskala Besar (PSBB) kepada Menteri Kesehatan yang diatur dalam Undang-Undang No. 6 Tahun 2018 tentang Karantina Kesehatan dan sejalan dengan Keppres RI Nomor 11 Tahun 2020 tentang
Penetapan Kedaruratan Kesehatan Masyarakat Corona Virus Desease 2019 (Covid-19).

Penyebaran Covid-19 yang tinggi ditandai dengan jumlah kasus serta jumlah kematian yang meningkat dan meluas di lintas wilayah dan lintas negara pastinya berdampak pada aspek politik, ekonomi, sosial, budaya, pertahanan dan keamanan, serta kesejahteraan masyarakat di Indonesia, maka Presiden mengeluarkan Peraturan Pemerintah Republik Indonesia Nomor 21 Tahun 2020, tentang Pembatasan Sosial Berskala Besar Dalam Rangka Percepatan Penanganan Corona Virus Disease 2019 (Covid-19).

Berdasarkan pada Undang-Undang dan Peraturan Pemerintah tersebut, beberapa Pemimpin Daerah yang meningkat penyebaran Covid-19 mengajukan PSBB ke kementerian Kesehatan. Pada tanggal 7 April 2020 Kementerian Kesehatan mengeluarkan Surat Keputusan Menteri Kesehatan Republik Indonesia No. HK.01/07/MENKES/239/2020 tentang Penetapan Pembatasan Sosial Berskala Besar di Wilayah Provinsi DKI Jakarta Dalam Rangka Percepatan Penanganan Corona Virus Disease 2019 (COVID-19). 


\section{Loyalitas Kreativitas \\ Aldi Masyarakat Kreatif}

P-ISSN 2722-2101, E-ISSN 2722-4201

Program Studi Ekonomi Manajemen Universitas Pamulang Jurnal LOKABMAS Kreatif Vol. 01, No. 03, Hal. 1-6

Email:jurnalkreatif.manajemen@gmail.com
Setelah dikeluarkan SK Menkes tersebut Gubernur DKI Jakarta mulai menerapkan PSBB di wilayah DKI Jakarta dari tanggal 10 April 2020 sampai dengan tanggal 23 April 2020. Apabila dalam waktu 14 hari tidak ada penurunan maka dapat diperpanjang lagi selama 14 hari berikutnya.

Dalam kegiatan Pengabdian Kepada Masyarakat kami melakukan kerjasama dengan Yayasan LAZ Nahwa Nur yang berlokasi di Kecamatan Parung Panjang, Bogor, Jawa Barat. Berdasarkan peraturan pemerintah Pusat dan Pemerintah Daerah Jawa Barat dikarenakan adanya Pandemi Covid-19 warga dilarang keluar rumah. Hal ini dilakukan untuk mencegah penyebaran Covid-19 di daerah sekitarnya. Jawa Barat merupakan provinsi yang semakin naik kasus Pandemi ini, sehingga dikeluarkannya Peraturan Daerah mengenai Pembatasan Sosial Berskala Besar (PSBB)

\section{RUMUSAN MASALAH}

Dengan mempertimbangkan latar belakang yang telah diutarakan diatas kami berinisiatif untuk membentuk pengabdian masyarakat yang ditujukan kepada para warga khususnya dhuafa binaan Nahwa Nur melalui progam pemberian bantuan sosial serta penyuluhan materi berkaitan dengan strategi pengembangan bisnis dengan pemanfaatan media daring di LAZ Nahwa Nur oleh dosen Universitas Pamulang yang beralamatkan Jl. Karadenan Kel No.21 A, Karadenan, Cibinong, Bogor, Jawa Barat 16711, Indonesia.

\section{TUJUAN PELAKSANAAN}

1. Mengetahui kondisi Pandemi Covid 19 yang berdampak pada para Dhuafa binaan LAZ Nahwa Nur.

2. Meningkatkan Pendapatan para Dhuafa binaan LAZ Nahwa Nur ditengah Covid 19.

3. Menerapkan metode dan Strategi Bisnis Online di masa Pandemi Covid 19 untuk meningkatkan pendapatan para Dhuafa binaan LAZ Nahwa Nur di tengah Pandemi Covid 19.

\section{TINJAUAN PUSTAKA}

Menurut Buchari Alma (2007:5) pengertian bisnis ditujukan pada sebuah kegiatan berorientasi profit yang memproduksi barang atau jasa untuk memenuhi kebutuhan masyarakat. Bisnis juga dapat diartikan sebagai suatu lembaga yang menghasilkan barang dan jasa yang dibutuhkan oleh masyarakat. Secara Etimologi, bisnis berarti keadaan dimana seseorang atau sekelompok orang sibuk melakukan pekerjaan yang menghasilkan keuntungan. Pendapat Ahli lain Skinner (1992) mendefinisikan bisnis sebagai pertukaran barang atau jasa yang saling menguntungkan atau memberi manfaat. Bisnis adalah sebuah aktivitas yang mengarah pada peningkatan nilai tambah melalui proses penyerahan jasa, perdagangan atau pengolahan barang (industri).

Untuk menghasilkan bisnis yang baik diperlukan strategi bisnis. Menurut Ibid (hal 339) strategi bisnis yang biasa disebut sebagai strategi bersaing dan dikembangkan pada level divisi serta menekankan pada perbaikan posisi persaingan produk barang/jasa perusahaan dalam segmen pasar yang dilayani oleh divisi tersebut.

Tujuan bisnis merupakan hasil akhir yang ingin dicapai oleh para pelaku bisnis dari bisnis yang mereka lakukan dan merupakan cerminan dari berbagai hasil yang diharapkan bisa dilakukan oleh bagian-bagian dari perusahaan (produksi, pemasaran, personalia, dll) yang akan menentukan kinerja dalam jangka panjang. Menurut Madnasir dan Khoiruddin dalam jurnal Etika Bisnis dalam Islam (2012:21) Sumber daya ekonomi yang dikelola secara efektif dan efisien dengan berbagai aktivitas bisnis bertujuan yaitu:

1. Menciptakan dan pengadaan barang atau jasa yang dibutuhkan oleh manusia baik individu, komunitas maupun masyarakat.

2. Mendapatkan pendapatan yang diinginkan lebih besar daripada biaya atau ongkos yang telah dikeluarkan oleh pengelola bisnis.

3. Menciptakan nilai tambah bagi pengelola bisnis dan masyarakat. 


\section{Loyalitas Kreativitas \\ Aldi Masyarakat Kreatif}

P-ISSN 2722-2101, E-ISSN 2722-4201

Program Studi Ekonomi Manajemen Universitas Pamulang Jurnal LOKABMAS Kreatif Vol. 01, No. 03, Hal. 1-6

Email:jurnalkreatif.manajemen@gmail.com
4. Menciptakan lapangan kerja bagi masyarakat.

Menurut Rangkuti (2006,7) strategi bisnis adalah strategi fungsional yang berorientasi pada fungsi-fungsi kegiatan manajemen, misalnya strategi pemasaran, strategi produksi atau operasional, strategi distribusi, strategi organisasi dan strategistrategi yang berhubungan dengan keuangan dari suatu bisnis.

Menurut Ward dan Peppard $(2002,69)$ strategi bisnis adalah sekumpulan Tindakan terintegrasi yang bertujuan untuk mencapai tujuan jangka panjang dan kekuatan perusahaan untuk menghadapi para pesaing. Suatu strategi bisnis meliputi beberapa hal seperti berikut:

Visi adalah pencapaian dari sebuah misi atau dapat diartikan sebagai sebuah pandangan masa depan dari sebuah bisnis yang menjadi tujuan umum sebuah perusahaan

Misi, yakni pernyataan yang memberikan arahan tentang apa yang akan dilakukan oleh sebuah perusahaan dalam mencapai visinya.

Business Driver: beberapa faktor kritis pendorong perubahan yang dapat memberikan focus pada bisnis sehingga dapat memenuhi sasarannya.

Objectives: sasaran-sasaran yang ditetapkan dan harus dipenuhi oleh perusahaan dalam pencapaian visi perusahaan.

Strategies: kebijakan atau tindakan langsng yang dipilih perusahaan sebagai alat untuk mencapai tujuan dan memenuhi misinya.

Critical Success Factor (CSF) adalah beberapa area kunci dimana sesuatu harus berjalan dengan baik sehingga keberhasilan bisnis dapat dicapai.

Business area Plans: perencanaan dari berbagai area bisnis yang ada yang berkaitan dengan strategi bisnis perusahaan.

Berikut ini adalah strategi marketing yang sedang trend dan perlu dikuasai oleh pelaku bisnis untuk membantu pemasaran produk.

\section{Content Marketing}

Konten adalah materi paling penting, karena setiap orang masuk ke dunia maya, mereka akan mencari sebuah konten dengan keyword yang mereka masukan. Banyak perusahaan yang masih belum memahami pentingnya trend dan bagaimana konten marketing melandasi hampir seluruh digital marketing. Konten merupakan dasar dari semua digital marketing dan sangat penting untuk menciptakan brand awareness serta merambah keramaian.

\section{Integrated Digital Marketing}

Media sosial dan konten memiliki peranan penting pada hasil pencarian. Banyaknya jenis media sosial saat ini mengharuskan sebuah brand memiliki sebanyak mungkin media sosial untuk menjangkau pelanggan lebih luas. Namun penggunaan banyak media sosial tersebut harus saling terintegrasi, sehingga tidak ada informasi yang tumpang tindih. Untuk itu pastikan bahwa setiap pendekatan yang dilakukan memberikan kemungkinan untuk mengikat mereka semua secara bersamaan demi mencapai suatu efektivitas yang maksimum.

\section{Embrace Relationship Marketing}

Sebuah brand harus berhubungan langsung dengan pelanggannya. Brand harus membina hubungan yang baik yang membuatnya tertarik dan merasa nyaman dengan penawaran yang berikan. Pahami apa yang pelanggan inginkan dan yakinkan dengan bahasa yang mudah diingat, menjanjikan, dan membuatnya benar-benar merasa apa yang ditawarkan tersebut masuk akal.

\section{Personalized Marketing}

Pendekatan marketing yang biasa terjadi di media tradisional dan televisi menjadi kurang efektif karena adanya kejenuhan media. Kita bisa melihat bagaimana adanya personalized marketing di situs e-commerce, email dan website yang menyesuaikan dengan iklan dan user interface demi kepentingan konsumen yang relevan. Ketika mengunjungi bisnis online sekali dan kemudian berkunjung lagi, website akan tahu siapa Anda. 


\section{Loyalitas Kreativitas \\ Aldi Masyarakat Kreatif}

P-ISSN 2722-2101, E-ISSN 2722-4201

Program Studi Ekonomi Manajemen Universitas Pamulang Jurnal LOKABMAS Kreatif Vol. 01, No. 03, Hal. 1-6

Email:jurnalkreatif.manajemen@gmail.com
5. Visual Marketing

Media visualisasi seperti video sangat mudah dicerna masyarakat dibandingkan tulisan pada koran maupun buku. Hal ini tentu saja bisa dimanfaatkan untuk bisa mempromosikan produk maupun layanan dengan menggunakan teknologi visual seperti video. Hal ini turut diperkuat dengan adanya fakta bahwa situs Youtube merupakan situs dengan peringkat ke-2 ter ramai di dunia dilihat dari jumlah pengunjungnya. Sejak saat itulah visual marketing terus bermunculan seperti Instagram, Pinterest dan juga Slideshare.

\section{HASIL DAN PEMBAHASAN}

Kegiatan Pengabdian Kepada Masyarakat yang didukung oleh Lembaga Penelitian dan Pengabdian Kepada Masyarakat(LPPM) Universitas Pamulang yang dilakukan oleh para dosen program studi Manajemen S1 dan Akuntansi S1 telah berjalan dengan lancar dan mendapat apresiasi yang tinggi di tempat pelaksanaan kegiatan PKM tersebut yaitu di Yayasan LAZ Nahwa Nur yang berlokasi di Kecamatan Parung Panjang, Bogor, Jawa Barat.

Harapan kami dengan pengabdian ini dapat memberikan bantuan sosial secara langsung dan tepat sasaran, serta membuka wawasan masyarakat khususnya terdampak pandemi Covid-19 tentang strategi pengembangan bisnis melalui media daring dan dengan ilmu yang diperoleh pada kegiatan ini diharapkan mampu memberikan semangat baru bagi para dosen dan tenaga pengajar sebagai contributor yang memotivasi khususnya bagi masyarakat sekitar yang membutuhkan, terlebih di masa pandemi covid-19 masih berlangsung.

\section{KESIMPULAN DAN SARAN Kesimpulan}

Kesimpulan dari pengabdian ini adalah sebelumnya para peserta kurang mengerti tentang bagaimana cara mengoptimalkan sumber daya yang dimiliki dengan pemanfaatan media daring yang mulai berkembang. Selain itu, tidak terjangkaunya bantuan sosial langsung dilapangan dikarenakan keterbatasan akses menuju lokasi terdampak. Setelah kegiatan PKM selesai dilakukan, masyarakat mendapatkan banyak manfaat secara langsung berupa moril dan materil sebagai bekal ilmu menghadapi tantangan didepan mata.

\section{Saran}

Dengan pengabdian ini, kami selaku pengabdi dapat memberikan bantuan sosial secara langsung dan tepat sasaran, serta membuka wawasan masyarakat khususnya para terdampak pandemi Covid-19 tentang strategi pengembangan bisnis melalui media daring dan dengan ilmu yang diperoleh pada kegiatan ini diharapkan mampu memberikan semangat baru bagi para dosen dan tenaga pengajar sebagai contributor yang memotivasi khususnya bagi masyarakat sekitar yang membutuhkan, terlebih disaat pandemi masih berlangsung

\section{DAFTAR PUSTAKA}

Buchari Alma (2007:5) pengertian bisnis Freddy Rangkuti. 2006. Riset Pemasaran. Gramedia Pustaka Utama, Jakarta

Peraturan Pemerintah Republik Indonesia Nomor 21 tahun 2020 Tentang Pembatasan Sosial Berskala Besar Dalam Rangka Percepatan Penanganan Corona Virus Disease 2019 (Covid-19);

Keputusan Presiden Republik IndonesiaNomor 11 tahun 2020 Tentang Penetapan Kedaruratan Kesehatan Masyarakat Corona Virus Disease 2019 (Covid- 19);

Peraturan Menteri Pendidikan Dan Kebudayaan Republik Indonesia Nomor 3 tahun 2020 Tentang Standar Nasional Pendidikan Tinggi; Peraturan Menteri Pendidikan Dan Kebudayaan Republik Indonesia Nomor 7 Tahun 2020 Tentang Pendirian, Perubahan, Pembubaran Perguruan Tinggi Negeri, Dan Pendirian, Perubahan, Pencabutan Izin Perguruan Tinggi Swasta;

AM Irfanudin, CD Manik, F Faisal (2019). PELATIHAN DIGITAL MARKETING UNTUK PENGEMBANGAN SUMBER 


\section{Loyalitas Kreativitas \\ Aldi Masyarakat Kreatif}

P-ISSN 2722-2101, E-ISSN 2722-4201

Program Studi Ekonomi Manajemen Universitas Pamulang Jurnal LOKABMAS Kreatif Vol. 01, No. 03, Hal. 1-6 Email:jurnalkreatif.manajemen@gmail.com
DAYA MANUSIA. Pengabdian Dharma Laksana 2(1)

AM Irfanudin, D Sunardi, R Sari, I Imbron, N Nariah. (2020). PERAN SEO DALAM MENINGKATKAN RELIABILITAS PEMASARAN PRODUK VIA MEDIA ONLINE PADA FORUM MUSLIMAH DEPOK. Dedikasi PKM, 1(1)

Elburdah, R. P., \& Oktrima, B. (2020). PENGARUH COMMUNITY OF PRACTICE PADA IMPLEMENTASI KNOWLEDGE MANAGEMENT PADA KANTOR KELURAHAN REMPOA. JURNAL LOKABMAS KREATIF, 1(2), 11-15.

Pasaribu, V. L. D., Susanti, F., \& Hartuti, E. T. K. (2019). Memotivasi Siswa dan Siswi SMK Letris Indonesia di Dalam Menentukan Pilihan Untuk Melanjutkan Pendidikan Atau Bekerja Setelah Lulus Sekolah. Jurnal Pengabdian Dharma Laksana, 1(2), 161-172.

Pasaribu, V. L. D., Elburdah, R. P., Sudarso, E., \& Fauziah, G. (2020). PENGGUNAAN MANAJEMEN WAKTU TERHADAP PENINGKATAN PRESTASI BELAJAR DI SMP ARAISIYAH. Jurnal ABDIMAS Tri Dharma Manajemen, 1(1).

Pasaribu, V. L. D., Agrasadya, A., Shabrina, N., \& Krisnaldy, K. (2020). MENJADI ENTERPRENEUR MUDA YANG MEMILIKI JIWA LEADERSHIP UNTUK MENGHADAPI MASA DEPAN. Abdi Laksana, 1(1).

Pasaribu, V. L. D., Sulaiman, S., Sutiman, S., Thaharudin, T., \& Purnomo, B. Y. (2020). PENGENALAN LETAK POSYANDU TERDEKAT DIKELURAHAN PISANGAN DENGAN MANAJEMEN PEMASARAN REVOLUSI 4.0 UNTUK MENINGKATKAN PENGETAHUAN MASYARAKAT LETAK DAN FUNGSI POSYANDU TERDEKAT PADA KELURAHAN PISANGAN. DEDIKASI PKM, 1(1), 105-110.

Priadi, A., Pasaribu, V. L. D., Virby, S., Sairin, S., \& Wardani, W. G. (2020). PENGUATAN EKONOMI KREATIF BERBASIS SUMBER DAYA DESA DIKELURAHAN REMPOA. Abdi Laksana, 1(3), 356-358.
Sedarmayanti, 2004, Manajemen Sumber Daya Manusia, Liberty, Yogyakarta

Surat Keputusan Menteri Kesehatan Nomor HK.01.07 /Menkes/239/2020, tentang Penetapan Pembatasan Sosial Berskala Besar di Wilayah Provinsi DKI Jakarta Dalam Rangka Percepatan Penanganan Corona Virus Disease 2019 (COVID 19);

Ward, John, Peppard, Joe. (2002). Strategic Planning for Information System. 3rd Edition. John Willey \& Sons, Buffins Lane, Chichester

\section{DOKUMENTASI KEGIATAN}
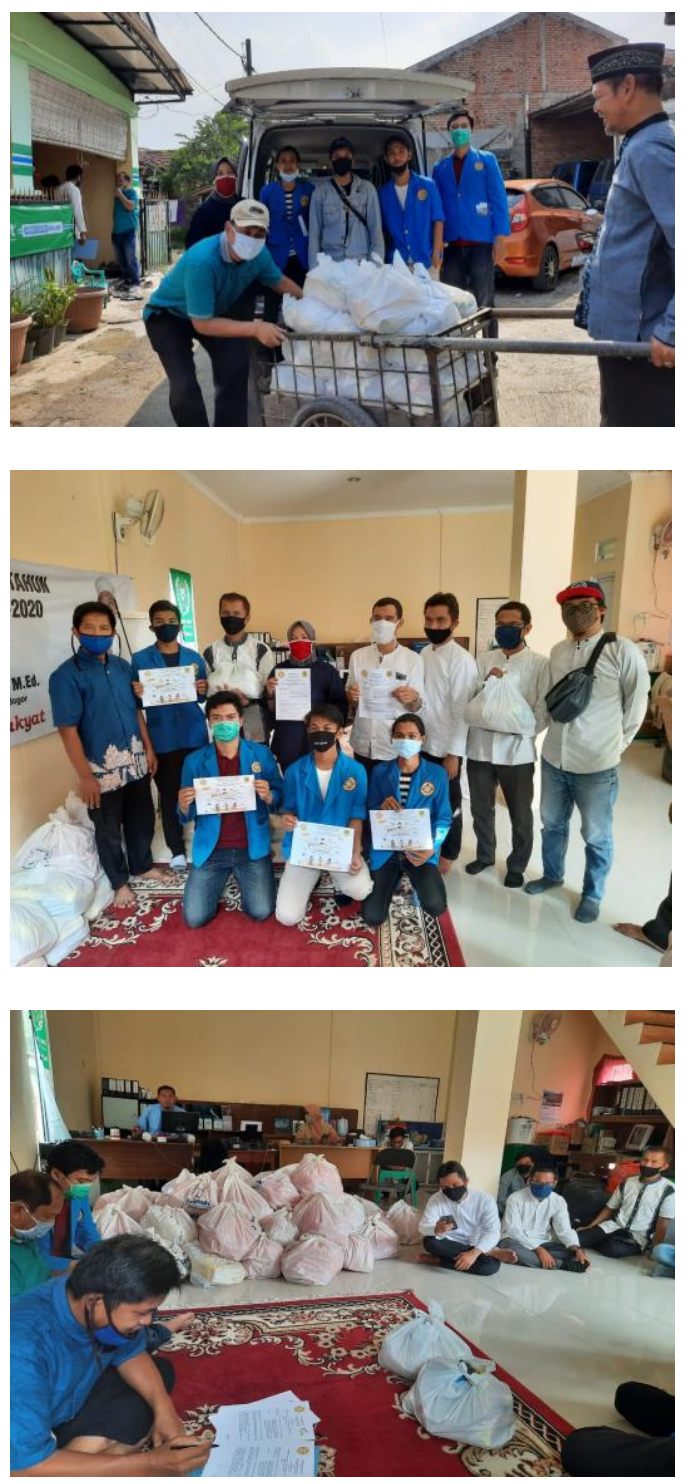